\title{
Two Human Cases of Echinococcus ortleppi Infection in the Lung and Heart in Vietnam
}

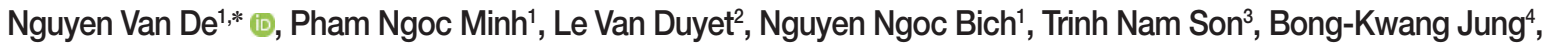 \\ Jong-Yil Chai ${ }^{4,5}$

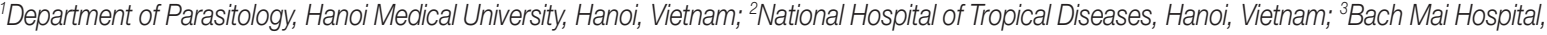 \\ Hanoi, Vietnam; ${ }^{4}$ Institute of Parasitic Diseases, Korea Association of Health Promotion, Seoul 07649 Korea; ${ }^{5}$ Department of Tropical Medicine and \\ Parasitology, Seoul National University College of Medicine, Seoul 03080, Korea
}

\begin{abstract}
This is a report of 2 cases of human hydatidosis caused by Echinococcus ortleppi in Vietnam. The patients were a 12-year-old male (case 1) having a cyst of $10.0 \times 9.0 \mathrm{~cm}$ size in the lung and a 50-year-old female with a $3.0 \times 3.3$ $\mathrm{cm}$-sized cyst in the heart. Eosinophilia was $33.7 \%$ in the male and $45.8 \%$ in the female patient. C-reactive protein was increased to $16.5 \mathrm{mg} / \mathrm{L}$ in the male and $18.2 \mathrm{mg} / \mathrm{L}$ in the female. Both patients were positive for ELISA at OD=2.5 and 3.1 , respectively. Echinococcus protoscolices were collected from the cysts by amniocentesis and surgery. The protoscolices were identified as $E$. ortleppi by morphology and analysis of mitochondrial NADH dehydrogenase 1 (nad1) gene sequence. Both patients were cured by surgical resection of the hydatid cyst combined with albendazole medication. The $E$. ortleppi infection in lung is the second report, and the other in the heart is the first in Vietnam.
\end{abstract}

Key words: Echinococcus ortleppi, hydatid, lung, heart, Vietnam

\section{INTRODUCTION}

Family Taeniidae consists of 2 genera, Echinococcus and Taenia [1]. Echinococcosis is an important zoonosis caused by tapeworms of the genus Echinococcus. Human echinococcosis continues to be a substantial cause of morbidity and mortality in many parts of the world [2-5]. Human echinococcosis occurs in 4 forms: cystic echinococcosis (CE), also known as hydatid disease or hydatidosis, caused by infection with the species complex of Echinococcus granulosus; alveolar echinococcosis (AE) caused by infection with Echinococcus multilocularis; and 2 forms of neotropical echinococcosis (NE), including polycystic disease caused by Echinococcus vogeli and unicystic disease caused by Echinococcus oligarthrus [6]. The adult stage develops in the small intestine of carnivores, and the larval stage develops in the viscera of a variety of mammalian species, including humans.

E. granulosus sensu stricto (G1) and Echinococcus ortleppi (G5)

- Received 13 June 2020, revised 26 June 2020, accepted 26 June 2020

*Corresponding author (ngvdeyhn@gmail.com)

(c) 2020, Korean Society for Parasitology and Tropical Medicine

This is an Open Access article distributed under the terms of the Creative Commons

Attribution Non-Commercial License (https://creativecommons.org/licenses/by-nc/4.0) which permits unrestricted non-commercial use, distribution, and reproduction in any

medium, provided the original work is properly cited. are haplotypes of the parasite formerly known as E. granulosus sensu lato, which in its larval stage causes cystic hydatidosis [7]. Now E. granulosus sensu lato is considered to be a complex of at least 4-5 different species that encompass 10 genotypes [8]. They include E. granulosus sensu stricto (genotypes G1, sheep strain; G2, Tasmanian sheep strain; G3, buffalo strain), Echinococcus equinus (G4, horse strain), E. ortleppi (G5, cattle strain), and Echinococcus canadensis (G6, camel strain; G7, pig strain; G8 \& G10, cervid strain) [7,8]. Humans or animals can be infected with the larval form (echinococcosis) in various organs; humans are incidentally infected [2-4]. Growing cysts may damage surrounding tissues, including blood vessels [4].

Of the 4 forms of echinococcosis, CE caused by the species complex of E. granulosus, including E. ortleppi, and AE by E. multilocularis are highly important $[9,10]$. CE occurs worldwide, whereas $\mathrm{AE}$ is restricted to the northern hemisphere. Two forms of NE have been identified in Central and South Americas [11]. Any associated clinical problems are dependent upon the number of cysts, their size, location, and the rate of growth. The organs most frequently affected are the liver and lungs, in approximately $65 \%$ and $25 \%$ of the cases, respectively [8], but may also be the kidneys, spleen, brain, heart, skeletal system, and musculature. Cysts are detected by ultrasound, $\mathrm{X}$-ray, computed tomography (CT), magnetic resonance imag- 
ing (MRI), or other imaging techniques. Anti-echinococcal antibodies can be detected by serological tests, including indirect fluorescent antibody test, complement fixation test, ELISA, Western blot, and other techniques [12].

Echinococcosis is distributed almost worldwide and especially common in such areas as Australia, Tasmania, New Zealand, southern and northern Africa, and South America [13], and also in some other regions, such as Central America, the Middle East, China, Italy, Spain, Greece, Russia, and the western US (Arizona, New Mexico, and California) [2]. In Italy, chest X-rays and lung images were described in 24 (85.7\%) of 28 confirmed patients most of which were with hepatic localization (96\%) [5]. In Asia, echinococcosis has been reported in Japan, China, South Korea, Mongolia, Thailand, Indonesia, Bangladesh, and India [14]. High prevalences of CE have been recorded from South America, Northern and Eastern Africa, Eurasia, and Australia [15]. In Vietnam, the first report of human echinococcosis due to E. ortleppi involving 2 cases was published in 2017 [16]. In the present study, we report 2 additional cases of human E. ortleppi infection in Vietnam; one patient had a cyst in the lung and the other had a cyst in the heart.

\section{CASE RECORD}

\section{Case 1}

The patient was a 12-year-old male residing in Bac Ninh Province of Delta in north Vietnam. He was a schoolboy and had lived in his hometown. He complained of chest pain in the right side in January 2019, and the severity of this symptom increased for 1 month. He visited the National Hospital of Pediatrics in Hanoi, Vietnam. The main clinical symptoms were chest pain and dyspnea, without fever and cough (Table 1). In chest MRI, a big nodular shadow circle, $9.0 \times 10.0 \mathrm{~cm}$ in size, was found with equal density in the left lobe of the lung (Fig. 1A). ELISA was positive for Echinococcus antigen $(\mathrm{OD}=2.5 / 0.3)$. Several hematological and biochemical values were increased; WBC of 12,000 cells $/ \mathrm{mm}^{3}$, eosinophilia of $33.7 \%$, and C-reactive protein (CRP) of $16.5 \mathrm{mmol} / \mathrm{L}$ (Table 2). The larvae (protoscolices) were collected from the cyst by amniocentesis (Fig. 2A). He was treated by surgery combined with albendazole medication at the dose of $400 \mathrm{mg} \times 2$ times/ day for 2 months, and recovered after the treatment.

\section{Case 2}

The patient was a 50-year-old female residing in Phu Tho Province of mountainous north Vietnam. She was a farmer

Table 1. Symptoms, signs, and treatment of the 2 patients

\begin{tabular}{lcc}
\hline Symptom and sign & 12-year-old male & 50-year-old female \\
\hline Fever & - & + \\
Pain in the chest & + & + \\
Cough & - & + \\
Dyspnea & + & + \\
Positive ELISA & OD $=2.5$ & OD $=3.1$ \\
Number of cysts & 1 & 1 \\
Cyst size (cm) & $10.0 \times 9.0$ & $3.0 \times 3.3$ \\
Place of cyst & lung & heart \\
Treatment & albendazole + surgery & albendazole + surgery \\
\hline
\end{tabular}
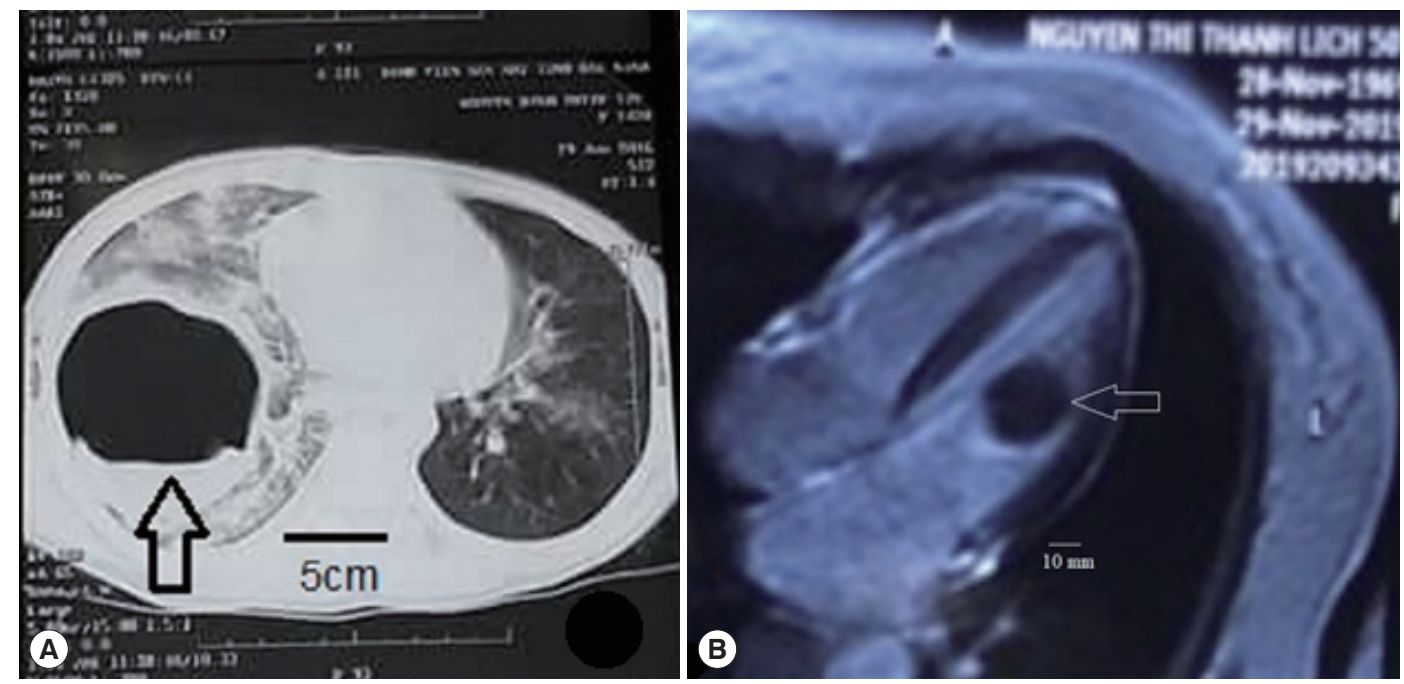

Fig. 1. The hydatid cyst in the lung (A) and heart $(B)$ of 2 patients in this study presented by MR images. 
and had lived in her hometown. She felt chest pain in the left side in October 2019 and visited the Bach Mai Hospital for examination. Her main clinical symptoms and signs were chest pain in the left side, dyspnea, fever of $38.5^{\circ} \mathrm{C}$, and severe cough (Table 1). In chest MRI, a nodular shadow (circle), 3.0 ×3.3

Table 2. Hematology and biochemistry values of the 2 cases

\begin{tabular}{|c|c|c|c|c|}
\hline Marker & Unit & $\begin{array}{l}\text { 12-year- } \\
\text { old male }\end{array}$ & $\begin{array}{l}\text { 50-year- } \\
\text { old female }\end{array}$ & Healthy range \\
\hline AST(SGOT) & $U / L$ & 39 & 40 & $2-40$ \\
\hline ALT(SGPT) & $U / L$ & 40 & 39 & $5-40$ \\
\hline $\mathrm{v}$-GT & U/L & 35 & 36 & $5-35$ \\
\hline Total bilirubin & umol/L & 6.6 & 15 & $<21$ \\
\hline Creatinine & $\mathrm{mmol} / \mathrm{L}$ & 63 & 90 & $53-100$ \\
\hline Urea & mmol/L & 5.3 & 6.5 & 2.5-7.5 \\
\hline WBC $^{a}$ & Cells $/ \mathrm{mm}^{3}$ & 12,000 & 15,000 & $4,000-10,000$ \\
\hline Neutrophils & $\%$ & 36.2 & 25 & 60-66 \\
\hline Eosinophils $^{a}$ & $\%$ & 33.7 & 45.8 & $2-8$ \\
\hline Basophils & $\%$ & 1.0 & 1.5 & $0-1$ \\
\hline Monocytes & $\%$ & 4.1 & 3.5 & $2-3$ \\
\hline Lymphocytes & $\%$ & 25.0 & 24.2 & $20-25$ \\
\hline C-reactive protein ${ }^{a}$ & $\mathrm{mg} / \mathrm{L}$ & 16.5 & 18.2 & $<6.0$ \\
\hline
\end{tabular}

ain abnormal range. $\mathrm{cm}$ in size with equal density, was found in the left ventricle of the heart (Fig. 1B). ELISA was positive for Echinococcus antigen $(\mathrm{OD}=3.1 / 0.3)$. Some hematology and biochemistry titers were increased; WBC 15,000 cells $/ \mathrm{mm}^{3}$, eosinophilia $45.8 \%$, and CRP $18.2 \mathrm{mg} / \mathrm{L}$ (Table 2). The cystic fluid was collected by amniocentesis, and the protoscolices were found under microscopy (Fig. 2B). She was treated by surgery combined with albendazole $400 \mathrm{mg} \times 2$ times/day for 2 months, and cured after the treatment.

\section{Molecular analysis of protoscolices from the cystic fluid}

The cyst (hydatid cyst) surgically excised contained numerous protoscolices, each of which had hooklets (Fig. 2A, B). The protoscolices had a spherical body of about $0.16 \times 0.14 \mathrm{~mm}$ in size with an invaginated scolex armed with 30 hooklets; each hooklet was $21 \mu \mathrm{m}$ in its longest diameter (Fig. 2A, B). These protoscolices were identified as E. ortleppi by a molecular method using mitochondrial NADH hydrogenase 1 (nad1) with $99-100 \%$ homology compared with E. ortleppi in GenBank; however, the homology with E. granulosus was only 93-

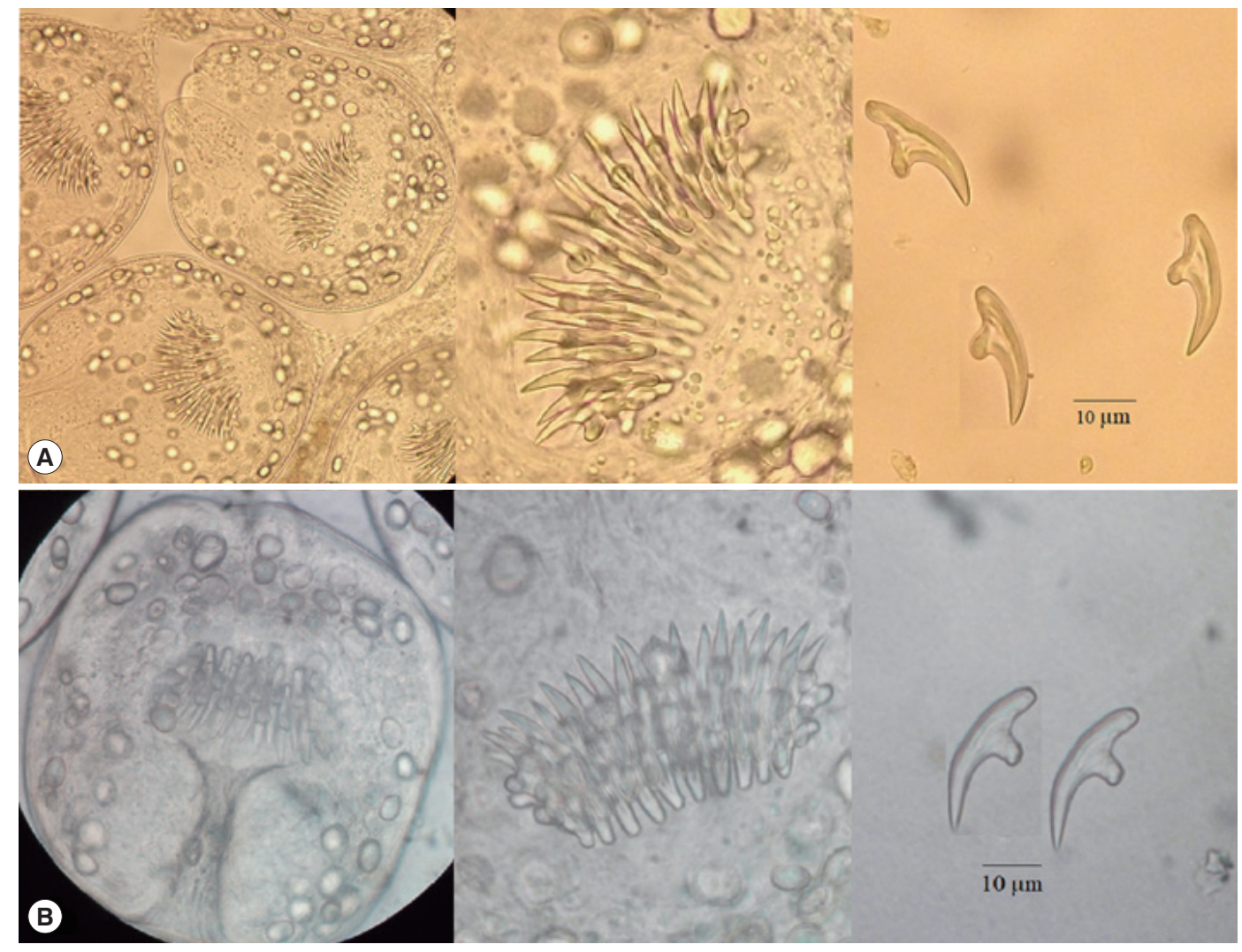

Fig. 2. The protoscolices and hooklets of Vietnamese Echinococcus ortleppi from the present cases. Note the larvae from case 1 (A) and case 2 (B). 
Table 3. Sequencing of mitochondrial NADH dehydrogenase 1 (nad1) gene of different Echinococcus species from GenBank compared with Echinococcus ortleppi from Vietnam

\begin{tabular}{|c|c|c|c|c|c|}
\hline Notation & Origin & Host & Length & Species & GenBank no. \\
\hline Eorvn1 & Vietnam & Human & $438 \mathrm{bp}$ & E. ortleppi ${ }^{\mathrm{a}}$ & - \\
\hline Eorvn2 & Vietnam & Human & $438 \mathrm{bp}$ & E. ortleppia & - \\
\hline Eor1 & Sudan & Camel & $438 \mathrm{bp}$ & E. ortleppi & JN637177.1 \\
\hline Eor2 & Unknown & Cattle & $438 \mathrm{bp}$ & E. ortleppi & AB235846.1 \\
\hline Eor3 & The Netherlands & Bos taurus & $438 \mathrm{bp}$ & E. ortleppi & DQ402037.1 \\
\hline Eor4 & The Netherlands & Cattle & $438 \mathrm{bp}$ & E. ortleppi & AJ237636.1 \\
\hline Eeq5 & Namibia & Zebra & $420 \mathrm{bp}$ & E. equinus & AJ508085.1 \\
\hline Egr6 & Iran & Camel & $438 \mathrm{bp}$ & E. granulosus & HM749618.1 \\
\hline Egr7 & Iran & Camel & $438 \mathrm{bp}$ & E. granulosus & HM749617.1 \\
\hline Eca8 & Poland & Human & 438 bp & E. canadensis & JX266822.1 \\
\hline Eca9 & Poland & Human & $438 \mathrm{bp}$ & E. canadensis & JX266818.1 \\
\hline
\end{tabular}

This report.

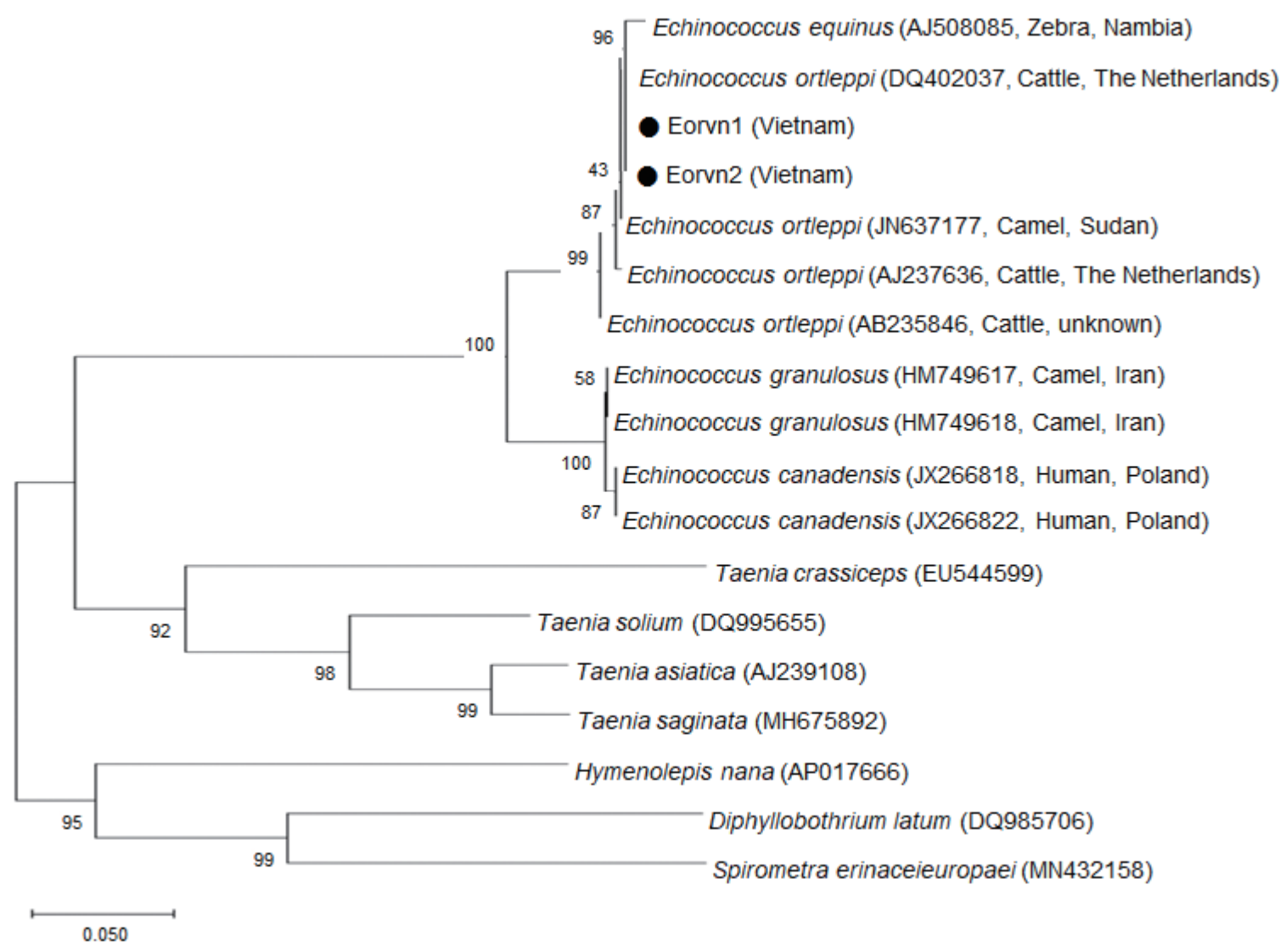

Fig. 3. A phylogenetic tree of Echinococcus ortleppi from 2 Vietnamese cases in comparison with reports from other countries based on a part of NADH dehydrogenase 1 (nad1) nucleotide sequences estimated by neighbor-joining method using the MEGA5.1 program. ( Eorvn1 and Eorvn2, Vietnamese E. ortleppi obtained in this study.

94\% (Table 3). The phylogenetic tree of E. ortleppi Vietnam isolates and other strains constructed from partial nad 1 sequences by the neighbor-joining (NJ) method using the MEGA5.1 program employing Tamura-nei model of nucleotide substitution with 1,000 bootstrap replications showed that the present isolates of Vietnamese E. ortleppi (Eorvn1 and Eorvn2) are one group with other geographical isolates of $E$. ortleppi available in GenBank (from The Netherlands, Sudan, and an unknown country) (Fig. 3). 


\section{DISCUSSION}

The present report of 2 cases of human echinococcosis is based upon the diagnosis of larvae from the surgically excised cysts. MRI clearly showed 1 cyst each, in the lung and the heart, in the 2 patients, respectively. The larval form of $E$. ortleppi was detected from bovines (cattle and buffaloes) in Italy in 2008 [7] and also in Southern Brazil in 2012 [6]. The geographical distribution of E. ortleppi is extended from Africa, to Central and South America, Central Europe, and Asia [7]. Human E. ortleppi infection has been detected in Brazil [10], France [8], Poland [12], Chile [13], and China [14]. Animal E. granulosus hydatid cysts are usually found in the liver or lungs of cattle, but E. ortleppi cysts are found in the lungs of cattle [17]. Animal E. ortleppi infection was also detected in onehumped camels in Sudan [15] and crested porcupines in Bosnia and Herzegovina [18].

Echinococcosis is very rare in Vietnam, and recent years, some cases were suspected as echinococcosis with watery cysts in the liver by ultrasound; however, no larvae or hooklets were collected in the cystic fluid [19]. In Vietnam, human cystic hydatidosis due to E. ortleppi infection was reported for the first time in 2017 with 2 cases, including a 42-year-old male and a 48-year-old female, both in the lungs with a single cyst of $6.0 \times 7.0 \mathrm{~cm}$ in size and 4 cysts of $5.0 \times 6.0,4.0 \times 4.0,3.5 \times 3.0$, and $2.5 \times 2.0 \mathrm{~cm}$ in size, respectively [16].

Animal E. ortleppi infection was first detected in red-shanked douc langurs in Vietnam [20]. In addition, in Southern Vietnam, Hoa and Tan [21] reported dogs (the reservoir host) infected with E. granulosus in 1967. In the present study, we detected 2 E. ortleppi patients treated with surgery combined with albendazole medication, $400 \mathrm{mg} / \mathrm{kg} \times 2$ times/day for 60 days, and both patients were cured. The mode of infection in these patients is unknown.

Dehkordi et al. [22] showed that the treatment of hydatid cysts with albendazole may be associated with the prevention of recurrence and reduction of the size and death of the hydatid cysts. The treatment is multimodal, including surgery and medication; albendazole has a central role in the medical therapy of this disease [23]. Both albendazole and mebendazole have favorable effects in patients suffering from multi-organ and multi-cystic diseases, particularly in inoperable primary liver or lung cases, and these medications can also prevent secondary echinococcosis; the best efficacy of medication is observed with the liver, lung, and peritoneal cysts [24]. Albenda- zole $400 \mathrm{mg}$ twice a day, in 3 cycles of 6 weeks with 2 weeks between cycles could cure $80 \%$ (18/22) of the cases [25], whereas surgery remains the mainstay of the treatment for large, active, complicated, or symptomatic hepatic hydatid cysts [26]. Termed puncture, aspiration, injection, and re-aspiration (PAIR) of hydatid cysts combined with chemotherapy with albendazole or mebendazole may also be applied [27].

In conclusion, 2 human cases with E. ortleppi infection in the lung and heart each have been diagnosed morphologically and molecularly in Vietnam. Both patients were cured by surgery combined with albendazole treatment. In Vietnam, human E. ortleppi infection in the lung is the second report, and the cyst in the heart is the first one.

\section{ACKNOWLEDGMENTS}

This research was funded by Vietnam National Foundation for Science and Technology Development (NAFOSTED) under a grant no. 106-YS.05-2014.08, and collaborated with the National Hospital of Pediatrics and Bach Mai Hospital, Hanoi, Vietnam.

\section{CONFLICT OF INTEREST}

We have no conflict of interest related to this work.

\section{REFERENCES}

1. World Health Organization. Echinococcosis fact sheet [Internet]; [cited 2020 April]. Available from: Who.int/new-room/factsheet/detail/echinococcus.

2. Center for Disease Control and Prevention, USA. Echinococcosis [Internet]; [cited 2020 April]. Available from: https://www.cdc. gov/dpdx/echinococcosis/index.html.

3. Schwabe CW. Current status of hydatid disease: a zoonosis of increasing importance. In Thompson RCA ed, The Biology of Echinococcus and Hydatid Disease. London, UK. George Allen \& Unwin. 1986, pp 81-113.

4. Zhang W, Wen H, Li J, Lin R, McManus DP. Immunology and immunodiagnosis of cystic echinococcosis: an update. Clin Dev Immunol 2012; 2012: 101895.

5. Miyazaki I. Helminthic Zoonoses. International Medical Foundation of Japan. Tokyo, Japan. 1991, pp. 247-258.

6. Balbinotti H, Santos GB, Badaraco J, Arend AC, Graichen DÂS, Haag KL, Zaha A. Echinococcus ortleppi (G5) and Echinococcus granulosus sensu stricto (G1) loads in cattle from Southern Brazil. Vet Parasitol 2012; 188: 255-260.

7. Casulli A, Manfredi MT, La Rosa G, Cerbo ARD, Genchi C, Pozio 
E. Echinococcus ortleppi and E. granulosus G1, G2 and G3 genotypes in Italian bovines. Vet Parasitol 2008; 155: 168-172.

8. Grenouillet F, Umhang G, Arbez-Gindre F, Mantion G, Delabrousse E, Millon L, Boué F. Echinococcus ortleppi infections in humans and cattle, France. Emerg Infect Dis 2014; 20: 2100-2102.

9. Petrone L, Cuzzi G, Colace L, Ettorre GM, Busi-Rizzi E, Schinina V, Pucillo L, Angeletti C, Pane S, Di Caro A, Bordi E, Girardi E, Pozio E, Corpolongo A, Teggi A, Brunetti E, Goletti D. Cystic echinococcosis in a single tertiary care center in Rome, Italy. BioMed Res Int 2013; 2013: 978146.

10. Ito A, Wen H, Yamasaki H. Taeniasis/Cysticercosis and Echinococcosis in Asia. Federation of Asian Parasitologists. Tokyo, Japan. AAA Committee. Asian Parasitology, Vol. 2. 2005, pp 1-234.

11. de la Rue ML, Takano K, Brochado JF, Costa CV, Soares AG, Yamano K, Yagi K, Katoh Y, Takahashi K. Infection of humans and animals with Echinococcus granulosus (G1 and G3 strains) and E. ortleppi in Southern Brazil. Vet Parasitol 2011; 177: 97-103.

12. Dybicz M, Borkowski PK, Jonas M, Wasiak D, Małkowski P. First report of Echinococcus ortleppi in human cases of cystic echinococcosis in Poland. Biomed Res Int 2019; 2019: 2474839.

13. Corrêa F, Stoore C, Horlacher P, Jiménez M, Hidalgo C, Rojas CAA, Barros GF, Ferreira HB, Hernández M, Cabrera G, Paredes R. First description of Echinococcus ortleppi and cystic echinococcosis infection status in Chile. PLoS ONE 2018; 13: e0197620.

14. Shi Y, Wan X, Wang Z, Li J, Jiang Z, Yang Y. First description of Echinococcus ortleppi infection in China. Parasit Vectors 2019; 12: 398.

15. Ahmed ME, Eltom KH, Musa NO, Ali IA, Elamin FM, Grobusch MP, Aradaib IE. First report on circulation of Echinococcus ortleppi in the one humped camel (Camelus dromedaries), Sudan. BMC Vet Res 2013; 9: 127.

16. De NV, Duyet LV. The first report of two cases of cystic echinococcosis in the lung by Echinococcus ortleppi infection, in Vietnam. Res Rep Trop Med 2017; 8: 45-51.

17. Kelly R, Chalier J. Echinococcus granulosus and ortleppi [Internet]; [cited 2020 June 4] Available from: https://www.vetstream.com/ treat/bovis/bug/echinococcus-granulosus.

18. Hodžić A, Alić A, Šupić J, Škapur V, Duscher GG. Echinococcus ortleppi, the cattle strain in a crested porcupine (Hystrix cristata): a new host record. Vet Parasitol 2018; 256: 32-34.

19. De NV, Khue PV. Zoonotic Parasites. Hanoi, Vietnam. Education Published House. 2009, pp 116-117.

20. Plesker R, Nadler T, Dinkel A, Romig T. A case of an Echinococcus ortleppi infestation in a red-shanked douc langur (Pygathrix nemaeus) in northern Vietnam. Vietnam J Primatol 2009; 3: 75-81.

21. Hoa LV, Tan VN. Concerning the presence of cestodes, Echinococcus granulosus (Batsch, 1786), in a wild dog, Cyon primaerus (Hodgs) in South Vietnam Bull Soc Pathol Exot Filiales 1967; 60: 64-71 (in French).

22. Dehkordi AB, Sanei B, Yousefi M, Sharafi SM, Safarnezhad F, Jafari R, Darani HY. Albendazole and treatment of hydatid cyst: review of the literature. Infect Disord-Drug Targets 2019; 19: 101-104.

23. Stamatakos M, Sargedi C, Stefanaki C, Safioleas C, Matthaiopoulou I, Safioleas M. Anthelminthic treatment: an adjuvant therapeutic strategy against Echinococcus granulosus. Parasitol Int 2009; 58: $115-120$

24. Stojkovic M, Zwahlen M, Teggi A, Vutova K, Cretu CM, Virdone R, Nicolaidou P, Cobanoglu N, Junghanss T. Treatment response of cystic echinococcosis to benzimidazoles: a systematic review. PLoS Negl Trop Dis 2009; 3: e524.

25. Craig PS, McManus DP, Lightowlers MW, Chabalgoity PA, Garcia HH, Gavidia CM, Gilman RH, Gonzalez AE, Lorca M, Naquira C, Nieto A, Schantz PM. Prevention and control of cystic echinococcosis. Lancet Infect Dis 2007; 7: 385-394.

26. Keong B, Wilkie B, Sutherland T, Fox A. Hepatic cystic echinococcosis in Australia: an update on diagnosis and management. ANZ J Surg 2018; 88: 26-31.

27. Smego RA Jr, Sebanego P. Treatment options for hepatic cystic echinococcosis. Int J Infect Dis 2005; 9: 69-76. 